\title{
Selection and Validation of Appropriate Reference Genes for qRT-PCR Analysis of Flowering Stages and Different Genotypes of Iris Germanica L.
}

\section{Yinjie Wang}

Institute of Botany, Jiangsu Province and Chinese Academy of Sciences

\section{Yongxia Zhang}

Institute of Botany, Jiangsu Province and Chinese Academy of Sciences

Qingquan Liu

Institute of Botany, Jiangsu Province and Chinese Academy of Sciences

Haiying Tong

Institute of Botany, Jiangsu Province and Chinese Academy of Sciences

Ting Zhang

Institute of Botany, Jiangsu Province and Chinese Academy of Sciences

Chunsun Gu

Institute of Botany, Jiangsu Province and Chinese Academy of Sciences

Liangqin Liu

Institute of Botany, Jiangsu Province and Chinese Academy of Sciences

Suzhen Huang

Institute of Botany, Jiangsu Province and Chinese Academy of Sciences

Haiyan Yuan ( $\square$ yuanhaiyan416@163.com)

Institute of Botany, Jiangsu Province and Chinese Academy of Sciences

\section{Research Article}

Keywords: Iris germanica L., reference gene, qRT-PCR, flowering, normalization

Posted Date: February 15th, 2021

DOI: https://doi.org/10.21203/rs.3.rs-191110/v1

License: (c) (i) This work is licensed under a Creative Commons Attribution 4.0 International License.

Read Full License 
1 Title: Selection and validation of appropriate reference genes for $q R T-P C R$ analysis of flowering

2 stages and different genotypes of Iris germanica $\mathbf{L}$.

3 Authors: Yinjie Wang, Yongxia Zhang, Qingquan Liu, Haiying Tong, Ting Zhang, Chunsun Gu,

4 Liangqin Liu, Suzhen Huang and Haiyan Yuan*

5 Address: Institute of Botany, Jiangsu Province and Chinese Academy of Sciences, Nanjing 210014,

6 China

$7 \quad *$ Corresponding author:

8 Haiyan Yuan

9 Institute of Botany, Jiangsu Province and Chinese Academy of Sciences

$10 \quad$ Nanjing 210014, China

11 Tel: +86-25-84347086

12 E-mail: yuanhaiyan416@163.com 


\section{Abstract}

Iris germanica L. is a perennial herbaceous plant that has been widely cultivated worldwide and is popular for its elegant and vibrantly colorful flowers. Selection of appropriate reference genes is the prerequisite for accurate normalization of target gene expression by quantitative real-time PCR. However, to date, the most suitable reference genes for flowering stages have not been elucidated in $I$. germanica. In this study, eight candidate reference genes were examined for the normalization of qRT-PCR in three I. germanica cultivars, and their stability were evaluated by four different algorithms (GeNorm, NormFinder, BestKeeper, and Ref-finder). The results revealed that $I g U B C$ and $I g G A P D H$ were the most stable reference genes in '00246' and 'Elizabeth', and IgTUB and IgUBC showed stable expression in '2010200'. $I g U B C$ and $\operatorname{Ig} G A P D H$ were the most stable in all samples, while $\operatorname{Ig} U B Q$ showed the least stability. Finally, to validate the reliability of the selected reference genes, the expression patterns of IgFT (Flowering Locus $T$ gene) was analyzed and emphasized the importance of appropriate reference gene selection. This work presented the first systematic study of reference genes selection during flower bud development and provided guidance to research of the molecular mechanisms of flowering stages in I. germanica.

Keywords: Iris germanica L., reference gene, qRT-PCR, flowering, normalization

\section{Introduction}

Quantitative real-time PCR (qRT-PCR) is a reliable and widely used technique to quantify target gene expression patterns in various fields of biological research, due to its high sensitivity, accuracy and reproducibility ${ }^{1-3}$. However, the accuracy of qRT-PCR is influenced by various factors, including the quantity of mRNA templates, enzymatic efficiency in cDNA synthesis and PCR amplification ${ }^{4}$. Thus, to avoid bias, it is necessary to select reliable reference genes that are steadily expressed under 
different experimental conditions before determining the expression pattern of a target gene by qRT-PCR.

Traditional reference genes, such as elongation factor 1 alpha $(E F 1 \alpha)$, glyceraldehyde-3-phosphate dehydrogenase $(G A P D H)$, actin $(A C T)$ and ubiquitin $(U B Q)$, are mostly involved in intermediary metabolism or other basic cellular processes ${ }^{5-7}$, and are therefore commonly accepted for normalization without the need for any validation for their stability. However, numerous studies indicate that the expression levels of these genes vary considerably at different developmental stages or throughout the entire lifecycle of plants ${ }^{8,9}$. A systematic study for each tested species is recommended for identifying the best potential reference genes. Furthermore, several statistical algorithms, such as GeNorm ${ }^{10}$, NormFinder ${ }^{11}$ and BestKeeper ${ }^{12}$, have been developed for the evaluation of potential reference gene(s) in different experimental systems.

Flowers of higher plants are reproductive organs that are widely studied and are important ornamental characteristics of ornamental plants. A number of reference genes have been reported for different flowering stages of various ornamental plants species, such as chrysanthemum ${ }^{13}$, petunia $^{14}$, azalea $^{15}$ and tree peony ${ }^{16}$, but little information is available concerning reference genes for Iris. Iris germanica L., which is often referred to as Pogon iris, is one of the most important ornamental species in the Iris genus ${ }^{17}$, the posture of the flower is peculiar and the flowers are rich and have high ornamental and economic value. However, the spring-time flowering habit and short duration of flowering of I. germanica hinder its year-round supply and economic benefits. To enable additional detailed and in-depth studies of the expression level of key genes involved in flowering, it is necessary to identify the stability of candidate reference genes at various flowering stages in I. germanica. Recently, studies have been shown that ACT11 performed well in different tissues but poorly in 
different flower development stages in I. germanica cultivar 'Huangjinjia'. Furthermore, TUA performed best in different flower development stages but was the worst in different tissues ${ }^{18}$. Nevertheless, limited information is available concerning reference genes for flowering stages in $I$. germanica.

In the present study, the expression stability of eight candidate reference genes, IgEFl $\alpha$, $\operatorname{Ig} G A P D H, \operatorname{IgACT6}, \operatorname{Ig} U B Q, \operatorname{Ig} U B C$ (ubiquitin-protein ligase), $\operatorname{IgEF} 1 \beta$ (elongation factor $1 \beta$ ), $\operatorname{IgPGK}$ (phosphoglycerate kinase), IgTUB (beta-tubulin), was validated by qRT-PCR during flower development in different cultivars of I. germanica. Four statistical algorithms, GeNorm ${ }^{10}$, BestKeeper ${ }^{12}$, NormFinder ${ }^{11}$, and Ref-finder (http://www.leonxie.com/referencegene.php) were used to evaluate the most suitable reference genes needed for normalization. To verify the usefulness of the selected reference genes, the relative expression levels of IgFT, a putative homolog of Flowering Locus $T$ (FT) gene in Arabidopsis, was analyzed during flower bud development and in different genotypes of $I$. germanica. This is the first report about the selection of reference genes during flower bud development and will benefit future studies on gene expression of flowering stages in I. germanica and other related species.

\section{Results}

\section{Assessment of primer specificity and amplification efficiency of reference genes.}

The names, primer sequences and amplicon length characteristics of the 8 reference genes are summarized in Table 1. The primer specificities were verified by agarose gel electrophoresis, only a specific product of the expected size was observed, and no primer dimers were detected (Supplementary Fig. S1). In addition, only a single peak was found in the melting curves of the amplified products of all genes, indicating that no primer dimers were generated (Supplementary Fig. 
79 S2). The amplification efficiency (E) of each reference gene varied from $98.47 \%$ for $I g G A P D H$ to $101.74 \%$ for $\operatorname{Ig} U B Q$, and the correlation coefficients $\left(R^{2}\right)$ ranged from

$80 \quad 0.9984$ to 0.9998 (Table 1). The amplicon size ranged from 107 for $I g A C T 6$ to 295 bp for $I g U B Q$.

\begin{tabular}{|c|c|c|c|c|c|c|c|}
\hline Gene & Description & $\begin{array}{l}\text { Accession } \\
\text { numbers }\end{array}$ & $\begin{array}{l}\text { Arabidopsis } \\
\text { ortholog }\end{array}$ & Primer sequence (forward/ reverse) & $\begin{array}{l}\text { Product } \\
\text { size (bp) }\end{array}$ & $\begin{array}{l}\text { Amplification } \\
\text { efficiency }(\%)\end{array}$ & $\mathrm{R}^{2}$ \\
\hline $\operatorname{IgEFI\alpha }$ & Elongation factor 1 alpha & MN602628 & At1G07940 & $\begin{array}{l}\text { 5'-ACCATACCAGGCTTGATAACTCC-3' } \\
\text { 5'-AGACTGGTACAAGGGTCCTACTCTC-3 }\end{array}$ & 171 & $100.63 \%$ & 0.9995 \\
\hline $\operatorname{IgGAPDH}$ & $\begin{array}{l}\text { Glyceraldehyde-3-phosphate } \\
\text { dehydrogenase }\end{array}$ & MN602629 & At2G24270 & $\begin{array}{l}\text { 5'-TTTGCTGACGACTCGGACAC-3' } \\
\text { 5'-CTTGGATTTGGTTGCTGCTAAT-3' }\end{array}$ & 204 & $98.47 \%$ & 0.9998 \\
\hline IgACT6 & Actin6 & MN602630 & At2G31200 & $\begin{array}{l}\text { 5'-TGCTGCTTTGATTGCGTGT-3' } \\
\text { 5'-AGCTCCATACAATCGACTCAGG-3' }\end{array}$ & 107 & $98.74 \%$ & 0.9985 \\
\hline $\operatorname{Ig} U B Q$ & Ubiquitin & MN602631 & At4G05320 & $\begin{array}{l}\text { 5'-GATGGTCGCACACTTGCTGA-3' } \\
\text { 5'-GGAGCCTGAGAACAAGATGGA-3' }\end{array}$ & 295 & $101.74 \%$ & 0.9997 \\
\hline $\operatorname{Ig} U B C$ & Ubiquitin-protein ligase & MN602632 & At5G53300 & $\begin{array}{l}\text { 5'-CCTCCCTTTCCAATCGCTAA-3' } \\
\text { 5'-AGGTGCTGCTGTCCATCTGTT-3', }\end{array}$ & 162 & $101.67 \%$ & 0.9997 \\
\hline $\operatorname{IgEFI\beta }$ & Elongation factor $1 \beta$ & MN602633 & At5G19510 & $\begin{array}{l}\text { 5'-TTGGAGGAGACCGTTCGC-3' } \\
\text { 5'-TCATTGGCAGGCTCAACAGT-3', }\end{array}$ & 173 & $100.64 \%$ & 0.9995 \\
\hline$I g P G K$ & Phosphoglycerate kinase & MN602634 & At1G56190 & $\begin{array}{l}\text { 5'-GTTGTGCCAGCGTCTGAAAT-3' } \\
\text { 5'-ACCTCGGCTACTCCCACTTT-3' }\end{array}$ & 263 & $101.19 \%$ & 0.9994 \\
\hline $\operatorname{IgTUB}$ & Beta-tubulin & MN602635 & At1G64740 & $\begin{array}{l}\text { 5'-GTTTGACTTCCAGTTTGGTTGTG-3' } \\
\text { 5'-GCAAAACAAACACCCGCTTA-3' }\end{array}$ & 274 & $98.77 \%$ & 0.9984 \\
\hline $\operatorname{IgF} 3 \mathrm{H}$ & Flavanone 3-hydroxylase & MN602636 & At3G51240 & $\begin{array}{l}\text { 5'-GGTTCATTGTCTCCAGCCATC-3' } \\
\text { 5'-ATTGCTTCGGAGAGGACCC-3', }\end{array}$ & 202 & $98.70 \%$ & 0.9991 \\
\hline
\end{tabular}

81 Table 1. Primer sequences and characteristics of PCR amplifications in I. germanica. 


\section{Expression levels and profiles of reference genes.}

The quantification cycle $(\mathrm{Cq})$ values of eight reference genes were assayed by qRT-PCR analysis, with lower $\mathrm{Cq}$ values representing relatively higher mRNA transcript levels. $\mathrm{Cq}$ values for each of the 8 candidate reference genes in three different genotypes of I. germanica are listed in supplementary Table S1. The average $\mathrm{Cq}$ values of these reference genes ranged from 19.83 to 27.61 for the highest and lowest expression levels, respectively, across all samples (Fig. 1). In addition, the standard deviations (SD) of $\mathrm{Cq}$ values were used to determine reference gene stability levels. Genes with relatively high $\mathrm{SD}$ of $\mathrm{Cq}$ values showed more variable expression than did those with lower SD. $I g G A P D H$ showed the least variation in gene expression $(23.69 \pm 0.36)$ and presented the lowest SD, while $I g E F 1 \beta$ showed the most variable levels of expression $(23.16 \pm 1.38)$.

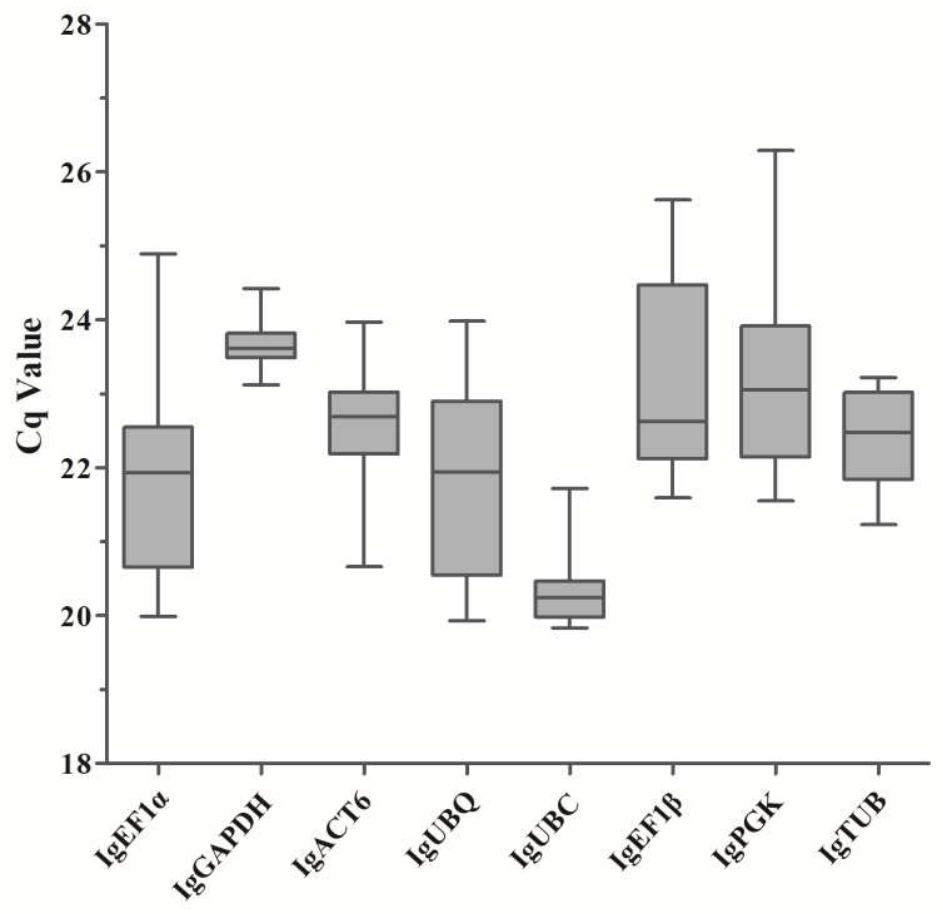

Figure 1. Cq values of the 8 candidate reference genes in all samples of $I$. germanica. Line across the box-plot of $\mathrm{Cq}$ value depicts median values. The outside box is determined by the 25 th and 75 th percentiles. The whiskers represent the maximum and minimum values. 


\section{Expression stability of reference genes.}

To further select the most appropriate reference gene for qRT-PCR-based analysis in the investigation of flower development across three different I. germanica cultivars, four software programs, GeNorm, NormFinder, BestKeeper and RefFinder were used to analyze the expression stability of each reference gene.

GeNorm analysis

GeNorm program was used to evaluate the expression stability of the 8 candidate reference genes by calculating average expression stability $(M)$ values based on the average pairwise variation among all the tested genes. According to GeNorm algorithm, stably expressed genes had $M$ values below 1.5, and a relatively low $M$ value indicates a relatively stable expression ${ }^{10}$. In this study, all of the tested genes showed high expression stability, with $M$-values of $<1.5$, indicating that they all conformed to basic requirements for function as reference genes. $\operatorname{IgUBC}$ and $\operatorname{IgGAPDH}$ were the most stable reference genes in both '00246' and 'Elizabeth', while IgTUB and $\operatorname{IgGAPDH}$ were identified as the most stable in '2010200'. In terms of the total samples tested, IgUBC and IgGAPDH were recommended as the most stable reference genes. In contrast, $\operatorname{Ig} U B Q$ with the highest $M$ value was identified as the least stable reference gene in all of the samples (Fig. 2). 

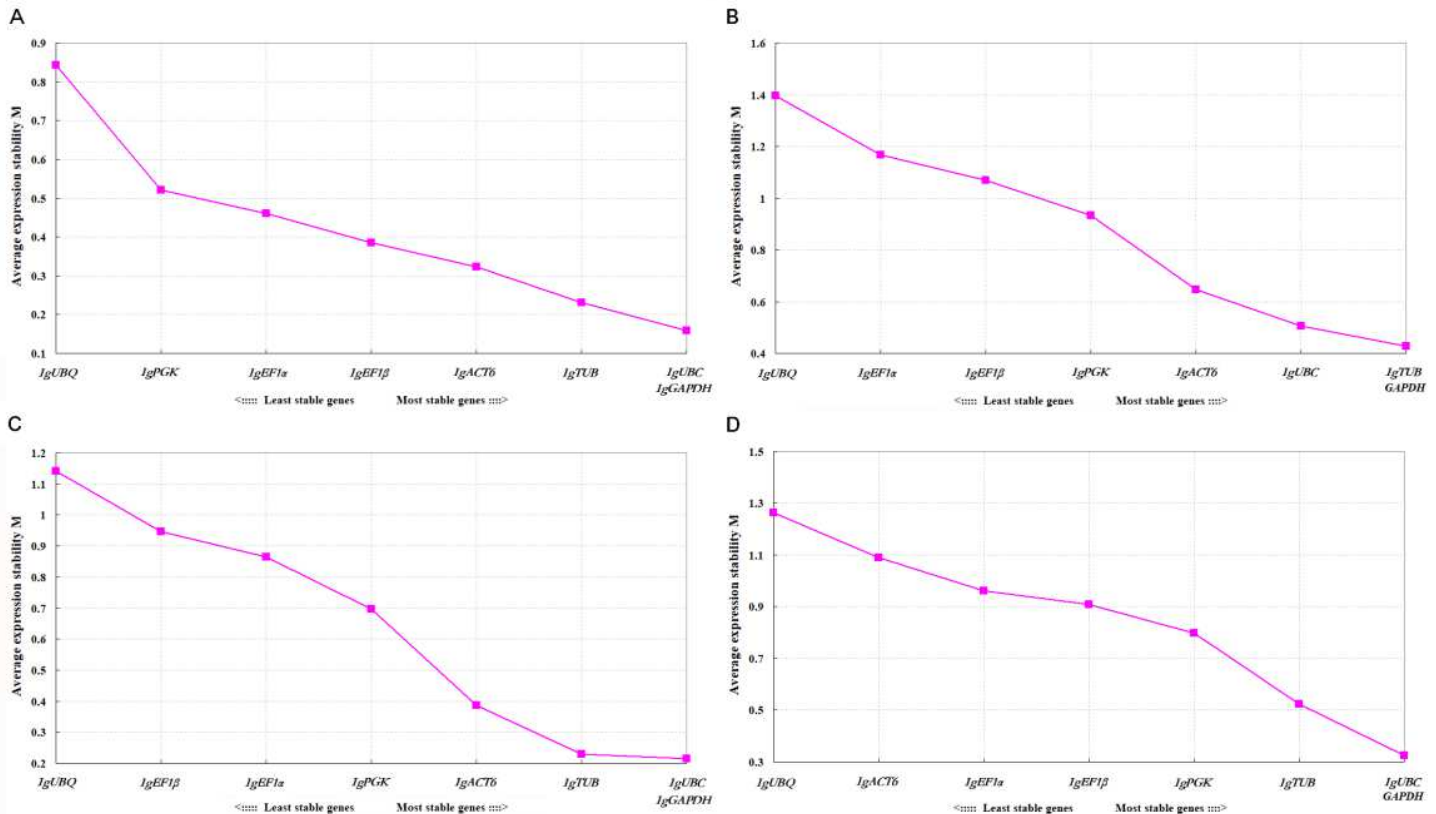

Figure 2. Average expression stability values (M) of 8 candidate reference genes predicted by GeNorm software. The most stable genes are on the right, while the least stable genes are on the left.

The optimal number of reference genes was also measured by determining the pairwise variation between equentially ranked genes $(\mathrm{Vn} / \mathrm{Vn}+1)$ based on the GeNorm algorithm (Fig. 3). Generally speaking, a cutoff of 0.15 (Vn value) has been recommended as the threshold to determine the optimal number of reference genes ${ }^{10}$. Our results reveal that the V2/3 values of the '00246', '2010200' and 'Elizabeth' samples were lower than 0.15 (Fig. 3), suggesting that two reference genes were sufficient for accurate normalization. However, the value of 0.15 should not be a fixed threshold, and higher cutoff values of $\mathrm{Vn} / \mathrm{n}+1$ have been shown in several reports ${ }^{19,20}$. Our data showed small variation between V2/3 and V3/4 across all the samples, suggesting that two reference genes were sufficient for normalization (Fig. 3). 

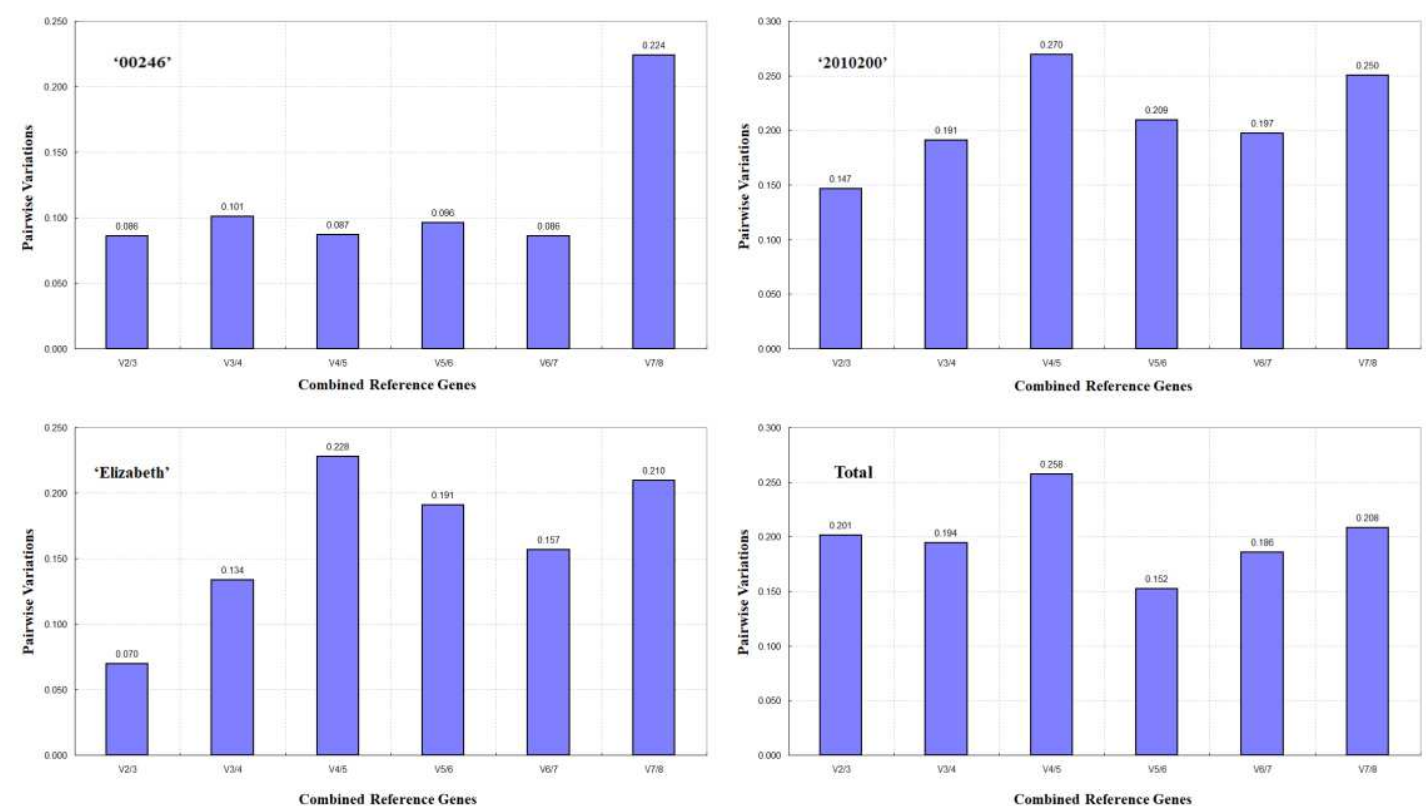

Figure 3. Pairwise variation $(\mathrm{V})$ of 8 candidate reference genes were calculated by GeNorm. $\mathrm{Vn} / \mathrm{Vn}+1$

value were used to determine the optimal number of reference genes.

NormFinder analysis

NormFinder is used to determine the stability value of reference genes, based on inter- and

intragroup variance in different sample groups ${ }^{11}$. The stability value is then calculated, with a relatively

low stability value meaning that the gene is relatively stable. Reference gene stability values were

calculated by NormFinder, as shown in Table 2. $\operatorname{Ig} U B C$ and $\operatorname{IgGAPDH}$ were the two most stable genes

among the total group, while $\operatorname{Ig} U B Q$ was the least stable. The top two most stably expressed genes ranking order generated by this method was slightly different from that of GeNorm.

\begin{tabular}{|c|c|c|c|c|c|c|c|c|}
\hline \multirow{2}{*}{ Rank } & \multicolumn{2}{|c|}{ '00246’ } & \multicolumn{2}{|c|}{ '2010200’ } & \multicolumn{2}{|c|}{ 'Elizabeth' } & \multicolumn{2}{|c|}{ Total } \\
\hline & Gene & Stability & Gene & Stability & Gene & Stability & Gene & Stability \\
\hline 1 & $I g G A P D H$ & 0.055 & $\operatorname{Ig} U B C$ & 0.187 & $\operatorname{Ig} U B C$ & 0.074 & $\operatorname{Ig} U B C$ & 0.112 \\
\hline 2 & $\operatorname{Ig} U B C$ & 0.055 & $I g G A P D H$ & 0.343 & $\operatorname{IgTUB}$ & 0.172 & $I g G A P D H$ & 0.207 \\
\hline
\end{tabular}




\begin{tabular}{|c|c|c|c|c|c|c|c|c|}
\hline 3 & $I g T U B$ & 0.078 & $I g T U B$ & 0.363 & $I g G A P D H$ & 0.200 & $\operatorname{IgTUB}$ & 0.442 \\
\hline 4 & IgACT6 & 0.268 & $I g P G K$ & 0.584 & IgACT6 & 0.534 & $I g P G K$ & 0.586 \\
\hline 5 & $I g E F I \beta$ & 0.308 & $I g E F 1 \beta$ & 0.811 & $I g P G K$ & 0.617 & IgEFIa & 0.715 \\
\hline 6 & IgEFla & 0.512 & IgACT6 & 0.814 & IgEFla & 0.723 & $I g E F I \beta$ & 0.772 \\
\hline 7 & $I g P G K$ & 0.537 & IgEFIa & 1.044 & $I g E F I \beta$ & 0.876 & IgACT6 & 0.820 \\
\hline 8 & $\operatorname{Ig} U B Q$ & 1.179 & $\operatorname{Ig} U B Q$ & 1.338 & $\operatorname{Ig} U B Q$ & 1.101 & $\operatorname{Ig} U B Q$ & 1.093 \\
\hline
\end{tabular}

135 Table 2. Expression stability analysis of 8 candidate reference genes calculated using NormFinder

136 software.

137 BestKeeper analysis

138 BestKeeper evaluates the stability of reference genes based on the standard deviation (SD) and

139 coefficients of variation $(\mathrm{CV})$ of $\mathrm{Cq}$ values, with relatively low SD and CV representing relatively high

140 stability $^{12}$. The results of BestKeeper analysis are listed in Table 3. IgGAPDH and IgUBC were

141 recommended as the most stable genes in '00246', 'Elizabeth' and across all the samples, which was

142 similar to the results from the GeNorm and NormFinder analysis. In '2010200' samples, IgTUB and

143 IgACT6 were detected as the most stable genes via BestKeeper analysis, whereas IgACT6 was ranked

144 fourth by GeNorm and sixth by NormFinder.

\begin{tabular}{|c|c|c|c|c|c|c|c|c|}
\hline \multirow[t]{2}{*}{ Rank } & \multicolumn{2}{|c|}{ ‘00246’ } & \multicolumn{2}{|c|}{ '2010200’ } & \multicolumn{2}{|c|}{ 'Elizabeth' } & \multicolumn{2}{|c|}{ Total } \\
\hline & Gene & $\mathrm{CV} \pm \mathrm{SD}$ & Gene & $\mathrm{CV} \pm \mathrm{SD}$ & Gene & $\mathrm{CV} \pm \mathrm{SD}$ & Gene & $\mathrm{CV} \pm \mathrm{SD}$ \\
\hline 1 & $\operatorname{IgGAPDH}$ & $0.33 \pm 0.08$ & $\operatorname{IgTUB}$ & $0.87 \pm 0.20$ & $I g G A P D H$ & $0.66 \pm 0.16$ & IgGAPDH & $0.89 \pm 0.21$ \\
\hline 2 & $\operatorname{Ig} U B C$ & $0.62 \pm 0.12$ & IgACT6 & $1.58 \pm 0.36$ & $\operatorname{Ig} U B C$ & $0.92 \pm 0.19$ & $\operatorname{Ig} U B C$ & $1.39 \pm 0.28$ \\
\hline 3 & $\operatorname{IgTUB}$ & $1.25 \pm 0.27$ & $I g G A P D H$ & $1.86 \pm 0.45$ & $\operatorname{IgTUB}$ & $2.96 \pm 0.66$ & $\operatorname{IgTUB}$ & $2.91 \pm 0.65$ \\
\hline 4 & $\operatorname{IgEFI} \beta$ & $1.74 \pm 0.39$ & $\operatorname{Ig} U B C$ & $2.58 \pm 0.53$ & IgEFla & $3.52 \pm 0.76$ & IgACT6 & $2.98 \pm 0.68$ \\
\hline 5 & IgACT6 & $2.00 \pm 0.47$ & $I g P G K$ & $4.63 \pm 0.97$ & $\operatorname{IgPGK}$ & $3.67 \pm 0.84$ & $I g P G K$ & $3.98 \pm 0.92$ \\
\hline 6 & $I g E F I a$ & $2.62 \pm 0.57$ & $\operatorname{IgEFI\beta }$ & $4.70 \pm 1.06$ & $\operatorname{IgACT6}$ & $3.71 \pm 0.84$ & $I g E F l a$ & $4.07 \pm 0.89$ \\
\hline 7 & $I g P G K$ & $2.86 \pm 0.64$ & IgEFIa & $5.77 \pm 1.34$ & $\operatorname{IgEF} 1 \beta$ & $4.26 \pm 0.98$ & $\operatorname{IgEF1} \beta$ & $4.38 \pm 1.00$ \\
\hline 8 & $\operatorname{Ig} U B Q$ & $5.22 \pm 1.12$ & $\operatorname{Ig} U B Q$ & $6.92 \pm 1.42$ & $\operatorname{Ig} U B Q$ & $4.46 \pm 0.95$ & $\operatorname{Ig} U B Q$ & $5.23 \pm 1.14$ \\
\hline
\end{tabular}

Table 3. Expression stability analysis of 8 candidate reference genes calculated using BestKeeper 
software.

RefFinder analysis

rankings of reference genes by integrating three common analysis programs: GeNorm, NormFinder and

156 in all the samples, '00246' and '2010200', and IgEF1 $\beta$ was the least stable gene in 'Elizabeth'. In the 157 all samples, $\operatorname{Ig} U B C$ and $\operatorname{Ig} G A P D H$ were purported to be the most stable reference genes, while $\operatorname{Ig} U B Q$

158 showed the least stability.

\begin{tabular}{|c|c|c|c|c|c|c|c|c|}
\hline Method & 1 & 2 & 3 & 4 & 5 & 6 & 7 & 8 \\
\hline \multicolumn{9}{|l|}{ Total } \\
\hline Comprehensive ranking & $U B C$ & GAPDH & $T U B$ & $P G K$ & EFla & ACT6 & $E F 1 \beta$ & $U B Q$ \\
\hline GeNorm & $U B C / G A P D H$ & & $T U B$ & $P G K$ & $E F 1 \beta$ & EFla & ACT6 & $U B Q$ \\
\hline NormFinder & $U B C$ & GAPDH & $T U B$ & $P G K$ & EFla & $E F 1 \beta$ & ACT6 & $U B Q$ \\
\hline Bestkeeper & GAPDH & $U B C$ & $T U B$ & ACT6 & $P G K$ & EFla & $U B Q$ & $E F 1 \beta$ \\
\hline \multicolumn{9}{|l|}{ '00246' } \\
\hline Comprehensive ranking & GAPDH & $U B C$ & $T U B$ & ACT6 & $E F 1 \beta$ & EFla & $P G K$ & $U B Q$ \\
\hline GeNorm & $U B C / G A P D H$ & & $T U B$ & ACT6 & $E F 1 \beta$ & EFla & $P G K$ & $U B Q$ \\
\hline NormFinder & $G A P D H$ & $U B C$ & $T U B$ & ACT6 & $E F 1 \beta$ & EFla & $P G K$ & $U B Q$ \\
\hline Bestkeeper & $G A P D H$ & $U B C$ & $T U B$ & $E F 1 \beta$ & ACT6 & EFla & $P G K$ & $U B Q$ \\
\hline
\end{tabular}




\begin{tabular}{|c|c|c|c|c|c|c|c|c|}
\hline Comprehensive ranking & $T U B$ & $U B C$ & GAPDH & ACT6 & $P G K$ & $E F 1 \beta$ & EFla & $U B Q$ \\
\hline GeNorm & $T U B / G A P D H$ & & $U B C$ & $P G K$ & $E F 1 \beta$ & EFla & ACT6 & $U B Q$ \\
\hline NormFinder & $U B C$ & GAPDH & $T U B$ & $P G K$ & $E F 1 \beta$ & ACT6 & EFla & $U B Q$ \\
\hline Bestkeeper & $T U B$ & ACT6 & GAPDH & $U B C$ & $U B Q$ & $P G K$ & $E F 1 \beta$ & EFla \\
\hline \multicolumn{9}{|l|}{ 'Elizabeth' } \\
\hline Comprehensive ranking & $U B C$ & GAPDH & $T U B$ & ACT6 & $P G K$ & EFla & $U B Q$ & $E F 1 \beta$ \\
\hline GeNorm & $U B C / G A P D H$ & & $T U B$ & ACT6 & $P G K$ & EFla & $E F 1 \beta$ & $U B Q$ \\
\hline NormFinder & $U B C$ & $T U B$ & GAPDH & ACT6 & $P G K$ & EFla & $E F 1 \beta$ & $U B Q$ \\
\hline Bestkeeper & GAPDH & $U B C$ & $T U B$ & ACT6 & $U B Q$ & EFla & $P G K$ & $E F 1 \beta$ \\
\hline
\end{tabular}

159 Table 4. Expression stability ranking of 8 candidate reference genes.

160 Validation of the selected reference genes.

161 To validate the reliability of the reference genes, the relative expression patterns of $\operatorname{IgFT}$ were

162 examined using different reference genes in the three cultivars. The two most stable reference genes

163 (IgGAPDH and $\operatorname{IgUBC}$ for '00246' and 'Elizabeth', IgTUB and $\operatorname{Ig} U B C$ for '2010200') and the least

164 stable reference genes (IgUBQ for '00246' and '2010200', IgEFI $\beta$ for 'Elizabeth') selected from the

165 analyses described above were used either alone or in combination for qRT-PCR analyses. As shown in

166 Fig. 4, although the overall relative expression patterns of $I g F T$ showed similar trends, differences were

167 found when the data were normalized to those of the different reference genes. When the least stable

168 gene $\operatorname{Ig} U B Q$ was used as the reference gene, the normalized expression levels of $I g F T$ in ' 00246 ' and

169 '2010200' significantly decreased compared with those of the stable genes IgGAPDH or IgUBC alone,

170 the combination of $\operatorname{Ig} G A P D H+\operatorname{Ig} U B C$ (for ' 00246 '), $\operatorname{IgTUB}$ or $\operatorname{IgUBC}$ alone or the combination of

$171 \operatorname{IgTUB}+\operatorname{Ig} U B C$ (for '2010200') (Fig. 4A-B). However, when the least stable gene IgEF1 $\beta$ was used

172 for normalization, the expression level of $I g F T$ dramatically increased compared to that of $I g G A P D H$,

$173 \operatorname{Ig} U B C$, or the combination of $\operatorname{IgGAPDH}+\operatorname{IgUBC}$ in 'Elizabeth' (Fig. 4C). The combination of

174 IgGAPDH/IgUBC was recommended as the optimum pair of reference genes for '00246' and 
A

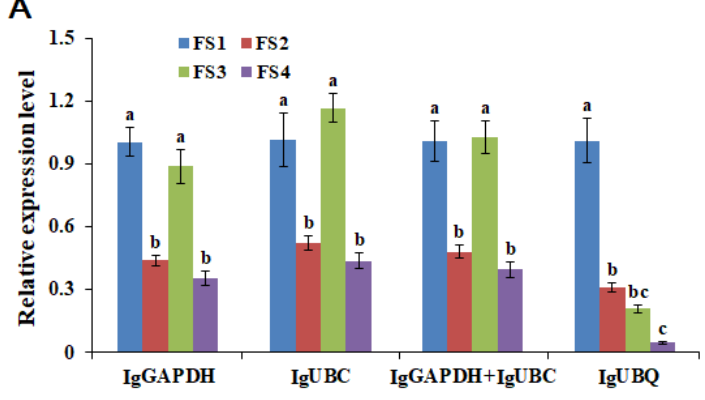

C

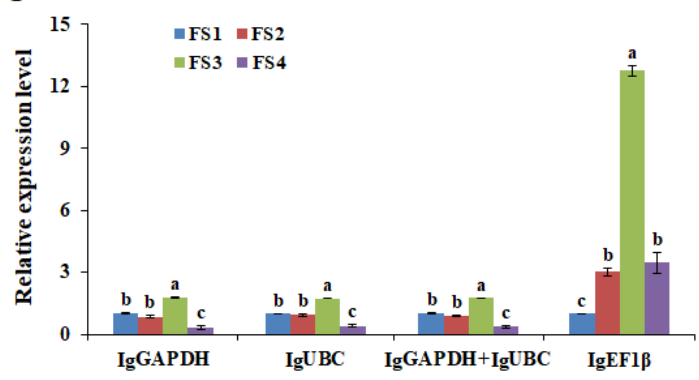

B

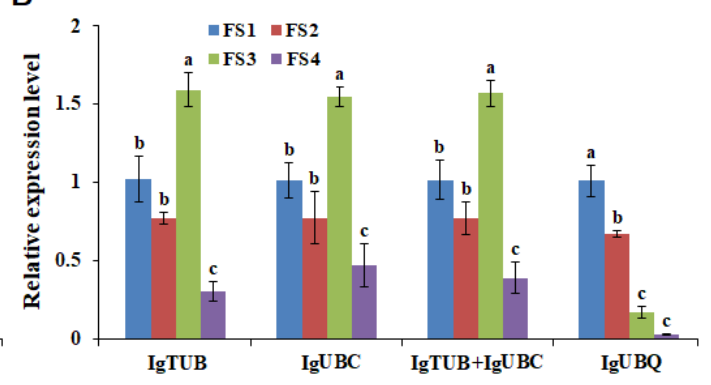

177

Figure 4. Relative quantification of $I g F T$ gene expression in different cultivars of I. germanica using validated reference genes for normalization. (A) The expression level of $I g F T$ in '00246'. (B) The expression level of $I g F T$ in '2010200'. (C) The expression level of $I g F T$ in 'Elizabeth'. The bars represent standard errors.

\section{Discussion}

Gene expression analyses are extremely important for revealing the molecular mechanisms that regulate important plant traits ${ }^{22,23}$. qRT-PCR has become the most powerful technique for quantification studies at the mRNA transcript leve $\mathrm{e}^{13}$. Selecting the appropriate reference genes is a necessary prerequisite for reliable qRT-PCR-based analysis. Ideally, an accurate reference gene should display stable expression in different tissues, in different organs, at different developmental stages and across different treatments ${ }^{24}$. In this study, we performed a systematic evaluation of 8 reference genes at different flowering stages and different genotypes of I. germanica cultivars. This study is the first 
attempt to identify the reference genes suitable for qRT-PCR normalization in flowering stages of $I$. germanica. The expression stability of various reference genes differed among the cultivars. Similar results were reported in tree peony, Panax ginseng and strawberry ${ }^{16,25,26}$. Different genetic backgrounds and biological processes between cultivars may have important effects on the expression stability of reference genes. These results indicate that the selection and validation of reliable reference genes for quantitative analysis of gene expression analysis were necessary for the different cultivars.

Three programs GeNorm, NormFinder and BestKeeper, which are based on different algorithms and analytical procedures, are widely used to select the most reliable reference genes by researchers ${ }^{27,28}$. In this study, we found discrepancies in the reference gene stability rankings and validation data generated by the three different algorithms above. The rankings created by GeNorm and NormFinder were similar, but they showed quite distinct differences from the ranking obtained by BestKeeper. For instance, IgACT6 was ranked among the top two stable genes by BestKeeper in '2010200' but was ranked in the middle or bottom portion by GeNorm and NormFinder. Moreover, across all the samples, IgACT6 was ranked among the top four stable genes by BestKeeper, whereas it was ranked seventh by GeNorm and NormFinder. These results are similar to those of many previous studies, possibly due to the different principles among the algorithms ${ }^{13,29}$. RefFinder, a comprehensive statistical program that integrates data from GeNorm, NormFinder, and BestKeeper, is used to evaluate the overall stability of reference gene expression ${ }^{30}$ Based on the comprehensive analysis by Ref-finder, $\operatorname{IgGAPDH}$ and $\operatorname{Ig} U B C$ for '00246' and 'Elizabeth' and IgTUB and IgUBC for '2010200' were identified as the most stable reference genes for qRT-PCR of target gene expression studies. These results suggest that all 8 reference genes exhibited differential stability among the three cultivars.

In this study, we evaluated 8 genes that have been widely used as candidate reference genes in 
212

213

many species. The results indicate that it is better to select different reference genes on the basis of the biological samples. Based on the results of our study involving different flower developmental stages, $\operatorname{Ig} U B C, \operatorname{Ig} G A P D H$ and $\operatorname{Ig} T U B$ were good candidates for normalization in all of the samples. Similar studies have also been conducted in other species, such as Tree Peony ${ }^{16}$, Rhododendrons ${ }^{31}$, Chinese cabbage $^{32}$, and Chrysanthemum lavandulifolium ${ }^{33}$. Moreover, UBQ was determined to be one of the most stable reference genes under $\mathrm{NaCl}$ and $\mathrm{Pb}$ stress in Iris. lactea var. chinensis $^{34}$, but this gene was ranked as the least stable reference genes in both '00246' and '2010200' in our study, which was similar to the findings in flower buds of Iris bulleyana ${ }^{35}$ and Rhizophora apiculate ${ }^{36}$. EF1 $\alpha$ and EF1 $\beta$ were determined to be the best suitable reference genes for all samples of various tissues in soybean ${ }^{37}$. In our study, these two genes ranked very low in all the samples, and $\operatorname{IgEF} 1 \beta$ exhibited the most unstable expression values in 'Elizabeth', which was similar to results in Moso bamboo ${ }^{38}$. ACT6 and $P G K$ were determined to be the most stable reference genes for proper normalization in flower buds of Iris bulleyana ${ }^{35}$ and Chrysanthemum across ploidy levels ${ }^{39}$, while these two genes were found to be not well suited in our study, similar to reports in I. lactea var. chinensis ${ }^{34}$. TUB, a member of the Tubulin gene family, has also been widely used as a reliable reference gene in Primula forbesii ${ }^{40}$ and peach ${ }^{41}$. Similarly, in our study, IgTUB was determined as the most stable reference gene in the flowers of '2010200'. However, this gene ranked very low under all the tested conditions in Iris bulleyana ${ }^{35}$. GAPDH has been reported as the most stable reference gene under PEG and cold stress in I. lactea var. chinensis $^{34}$ and at different flower developmental stages in tree peony ${ }^{16}$, but it showed unstable expression under various environmental conditions in garlic plants ${ }^{42}$. In our study, IgGAPDH was the most stable reference gene across all flower developmental stages in '00246'. In addition, $\operatorname{Ig} U B C$ was ranked first in 'Elizabeth' and was also the most stable reference gene in all the samples, which was 
similar to the findings in all samples of I. lactea var. chinensis ${ }^{43}$. These results highlight the fact that the choice of reference genes for normalization should be specific. Even though the samples belong to the same type and are from the same species (but belong to different lines), they may have different sets of reference genes. Therefore, it is necessary to select and verify reliable reference genes for quantitative gene expression analysis, whether for different species or for different cultivars.

To illustrate the reliability of the reference genes, the expression levels of the $I g F T$ gene were normalized by using the most stable or least stable reference genes. The results showed that the relative expression level of $I g F T$ exhibited a clear pattern in all three cultivars when the stable reference genes $\operatorname{IgGAPDH}, \operatorname{IgUBC}$, and $\operatorname{Ig} T U B$ or a combination of them were used (Fig. 4). The relative transcript abundance presented conflicting results when the least stable genes, $\operatorname{Ig} U B Q$ or $\operatorname{IgEF} 1 \beta$ were used as internal controls. Therefore, the selection of suitable internal control genes is critically important for normalization of target gene expression data by qRT-PCR.

In summary, the current study provides the first comprehensive analysis of the selection of stable reference genes as internal controls for qRT-PCR-based analysis of target gene expression in different flowering stages and different genotypes of I. germanica cultivars. IgGAPDH combined with $\operatorname{IgUBC}$ was recommended as the optimal reference gene in '00246' and 'Elizabeth', while IgUBC/IgTUB was identified as the best combination for '2010200'. This research is the first report on the validation of candidate reference genes across flower developmental stages of three different I. germanica cultivars, which will provide basic data for research on the molecular mechanism underlying flower development in this species, and lays a foundation for similar studies in other related species.

\section{Materials and methods}

\section{Plant material.}



liquid nitrogen and stored at $-80^{\circ} \mathrm{C}$ until RNA extraction. The experiment included three biological replicates.

\section{RNA isolation and cDNA synthesis.} manufacturer's instructions. Total RNA was pretreated with RNase-free DNase I (TaKaRa, Dalian, China) at $37^{\circ} \mathrm{C}$ for $30 \mathrm{~min}$ to eliminate potential DNA contamination. The integrity of the total RNA instructions. 
and IgTUB were selected from among homologs of traditional housekeeping genes previously used for

flower development ${ }^{13,44}$. The potential homologs of 8 reference genes were identified from the

281

282 transcriptomic data sequences of Iris lactea var. chinensis $^{45}$. All the candidate reference genes were cloned in Stage 4 samples and confirmed through sequencing. Primers were designed using Primer 5.0 software (Premier Biosoft International) with melting temperatures (TM) of $81.6-89.8^{\circ} \mathrm{C}$, primer lengths of 18-25 bp and amplicon lengths of 107-295 bp (Table 1). The performance of the primers was tested by qPCR and the specificity of the primer amplicons was further verified by $2 \%(w / v)$ gel electrophoresis.

\section{Quantitative real-time PCR (qRT-PCR).}

qPCR was performed using a Mastercycler ep realplex 2S device (Eppendorf, Germany) in conjunction with $\mathrm{SYBR}^{\circledR}$ Premix Ex Taq ${ }^{\mathrm{TM}}$ II (TaKaRa, Dalian, China). Reactions were performed in a $20 \mu \mathrm{L}$ mixture consisting of $5 \mu \mathrm{L}$ of diluted cDNA, $0.6 \mu \mathrm{L}$ of each amplification primer $(10 \mu \mathrm{M}), 10$ $\mu \mathrm{L}$ of $2 \times$ SYBR Premix and $3.8 \mu \mathrm{L}$ of $\mathrm{ddH}_{2} \mathrm{O}$. The amplification program comprised an initial denaturation step $\left(95^{\circ} \mathrm{C}\right.$ for $\left.2 \mathrm{~min}\right)$, followed by 40 cycles of $95^{\circ} \mathrm{C}$ for $5 \mathrm{~s}, 60^{\circ} \mathrm{C}$ for $30 \mathrm{~s}$, and $72^{\circ} \mathrm{C}$ for $30 \mathrm{~s}$, and a melting curve protocol $\left(60-95^{\circ} \mathrm{C}\right.$ with a temperature increment of $\left.0.5^{\circ} \mathrm{C} \mathrm{s}^{-1}\right)$. Each qRT-PCR was performed for three biological and three technical replicates, and negative controls were included for each primer pair. Amplification efficiency $(\mathrm{E})$ and correlation coefficient $\left(R^{2}\right)$ values were obtained from standard curves generated using a 10-fold diluted cDNA series ${ }^{46}$.

\section{Data analysis.}

The stability of the eight candidate reference genes was assessed using GeNorm ${ }^{10}$, NormFinder software $^{11}$, BestKeeper ${ }^{12}$, and Ref-finder (http://www.leonxie.com/referencegene.php). For GeNorm 
and NormFinder analysis, quantification cycle $(\mathrm{Cq})$ values were transformed into relative expression levels using the formula: $2^{-\Delta \mathrm{Cq}}$, in which $\Delta \mathrm{Cq}=$ each corresponding $\mathrm{Cq}$ value - the minimum $\mathrm{Cq}$ value ${ }^{16}$. The expression stability measurement $(M)$ was determined by the GeNorm program based on the average pairwise variations (V) among all the other reference genes. NormFinder program estimates intra- and intergroup variations, and the lowest stability is ranked the highest. Calculations of the BestKeeper program are calculated based on the coefficients of variation (CV) and the standard deviations (SD) of the $\mathrm{Cq}$ values, and the lowest $\mathrm{CV}$ and $\mathrm{SD}$ were used as detection indexes for the most-stable reference genes. Ref-finder is an online tool that integrates the results of the currently available major computational programs, including GeNorm ( $M$ values), NormFinder (stability values), BestKeeper (CV and SD), and $\Delta \mathrm{Cq}$ values.

\section{Validation of selected reference genes.}

To validate the influence of the choice of different reference genes on the final normalized outcome, the relative expression levels of $I g F T$ which plays an important role in promoting flowering ${ }^{47}$ in three cultivars were analyzed using individual stably expressed or unstably expressed genes or a combination of stable reference genes, as determined by GeNorm $^{48}$. The primers used for $I g F T$ are presented in Table 1. The fold change of gene expression was calculated using the $2^{-\Delta \Delta \mathrm{Ct}} \operatorname{method}^{22}$.

\section{Conclusions}

This research provided the first systematic analysis for the selection of stable reference genes as the internal control in qRT-PCR analysis in different flowering stages and different genotypes of $I$. germanica cultivars. Analysis using GeNorm, NormFinder, BestKeeper, and Ref-finder revealed that $I g U B C, \operatorname{Ig} G A P D H$, and $I g T U B$ could be considered as appropriate reference genes for gene expression analysis in future molecular researches that aim to understand the mechanisms of flowering stages in $I$. 


\section{References}

324

1. VanGuilder, H. D., Vrana, K. E. \& Freeman, W. M. Twenty-five years of quantitative PCR for gene expression analysis. Biotechniques 44, 619-626, https://doi.org/ 10.2144/000112776 (2008).

2. Bustin, S. A. et al. The MIQE guidelines: minimum information for publication of quantitative real-time PCR experiments. Clin Chem 55, 611-622, https://doi.org/10.1373/clinchem.2008. 112797 (2009).

3. Artico, S., Nardeli, S. M., Brilhante, O., Grossi-de-Sa, M. F. \& Alves-Ferreira, M. Identification and evaluation of new reference genes in Gossypium hirsutum for accurate normalization of real-time quantitative RT-PCR data. BMC Plant Biol 10, 49, https://doi.org/10.1186/ 1471-2229-10-49 (2010).

4. Derveaux, S., Vandesompele, J. \& Hellemans, J. How to do successful gene expression analysis using real-time PCR. Methods 50, 227-230, https://doi.org/10.1016/j.ymeth.2009.11.001 (2010)

5. Kozera, B. \& Rapacz, M. Reference genes in real-time PCR. J Appl Genet 54, 391-406, https://doi.org/10.1007/s13353-013-0173-x (2013).

6. Xiao, X. L. et al. Validation of suitable reference genes for gene expression analysis in the halophyte Salicornia europaea by real-time quantitative PCR. Frontiers in Plant Science 5, 788, https://doi.org/10.3389/fpls.2014.00788 (2014)

7. Delporte, M., Legrand, G., Hilbert, J. L. \& Gagneul. D. Selection and validation of reference genes for quantitative real-time PCR analysis of gene expression in Cichorium intybus. Front. Plant Sci $\mathbf{6}$, 651, https://doi.org/doi:10.3389/ fpls.2015.00651 (2015).

8. Niu, X. P. et al. Selection of reliable reference genes for quantitative real-time PCR gene 
expression analysis in Jute (Corchorus capsularis) under stress treatments. Front. Plant Sci 6, 848, https://doi.org/10.3389/fpls.2015.00848 (2015).

9. Zhang, Y. X. et al. Selection of suitable reference genes for quantitative real-time PCR gene expression analysis in Salix matsudana under different abiotic stresses. Sci Rep 7, 40290, https://doi.org/10.1038/ srep40290 (2017).

10. Vandesompele, J. et al. Accurate normalization of real-time quantitative RT-PCR data by https://doi.org/10.1186/gb-2002-3-7 -research0034 (2002).

11. Andersen, C. L., Jensen, J. L. \& Ørntoft, T. F. Normalization of real-time quantitative reverse 
15. Yi, S. J. et al. Selection of reliable reference genes for gene expression studies in Rhododendron micranthum Turcz. Sci Hortic-Amsterdam 138, 128-133, https://doi.org/10.1016/j.scienta.2012.02. 013 (2012).

16. Li, J., Han, J. G., Hu, Y. H. \& Yang, J. Selection of reference genes for quantitative real-time PCR during flower development in tree peony (Paeonia suffruticosa Andr.). Front. Plant Sci 7, 516, https://doi.org/10.3389/fpls.2016.00516 (2016).

17. Linnegar, S. \& Hewitt, J. Irises Octopus Publishing Group.(London, 2008).

18. Wang, Y. J. et al. Reference gene selection for qRT-PCR normalization in Iris germanica L. Phyton-Int J Exp Bot 90, 277-290, https://doi.org/:10.32604/phyton.2020.011545 (2020).

19. Silveira, É. D., Alves-Ferreira, M., Guimarães, L. A., da Silva, F. R. \& Carneiro, V. T. Selection of reference genes for quantitative real-time PCR expression studies in the apomictic and sexual grass Brachiaria brizantha. BMC Plant Biol 9, 84, https://doi.org/10.1186/1471-2229-9-84 (2009).

20. Marum, L., Miguel, A., Ricardo, C. P. \& Miguel, C. Reference gene selection for quantitative real-time PCR normalization in Quercus suber. PLoS One 7, e35113, https://doi.org/10.1371/ journal.pone.0035113 (2012).

21. Xie, F. L., Xiao, P., Chen, D. L., Xu L., \& Zhang, B. H. miRDeepFinder: a miRNA analysis tool for deep sequencing of plant small RNAs. Plant Mol Biol 80, 75-84, https://doi.org/10.1007/ s11103-012-9885-2 (2012).

22. Huggett, J. F., Dheda, K., Bustin, S. A. \& Zumla, A (2005) Real-time RT-PCR normalisation; strategies and considerations. Genes Immun 6:279-284. https://doi.org/10.1038/sj. gene.6364190 (2012).

23. Chen, Y. et al. Cold acclimation induces freezing tolerance via antioxidative enzymes, proline 
metabolism and gene expression changes in two chrysanthemum species. Mol Biol Rep 41, 815-822, https://doi.org/ 10.1007/s11033-013-2921-8 (2014).

24. Chapman, J. R. \& Waldenström, J. With reference to reference genes: a systematic review of endogenous controls in gene expression studies. PLoS One 10, e0141853, https://doi.org/10.1371/ journal.pone.0141853 (2015).

25. Wang, M. \& Lu, S. Validation of suitable reference genes for quantitative gene expression analysis in Panax ginseng. Front. Plant Sci 6, 1259, https://doi.org/10.3389/fpls.2015.01259 (2016).

26. Galli, G. G. et al. YAP drives growth by controlling transcriptional pause release from dynamic enhancers. Molecular cell 60, 328-337, https://doi.org/10.1016/j.molcel. 2015.09.001 (2015).

27. He, Y., Yan, H., Hua, W., Huang, Y. \& Wang, Z. Selection and validation of reference genes for quantitative real-time PCR in Gentiana macrophylla. Front. Plant Sci 7, 945, https://doi.org/ 10.3389/fpls.2016.00945 (2016).

28. Tang, F. et al. Selection and validation of reference genes for quantitative expression analysis of miRNAs and mRNAs in Poplar. Plant Methods 15, 35, https://doi.org/10.1186/s13007-019 -0420-1 (2019).

29. Shivhare, R. \& Lata, C. Selection of suitable reference genes for assessing gene expression in pearl millet under different abiotic stresses and their combinations. Sci Rep 6, 23036, https://doi.org/ 10.1038/srep23036 (2016).

30. Kim, H. et al. RNA-Seq analysis of spatiotemporal gene expression patterns during fruit development revealed reference genes for transcript normalization in plums. Plant Mol Biol Rep 33, 1634-1649, https://doi.org/ 10.1007/s11105-015-0860-3 (2015)。

31. Xiao, Z. et al. Selection of reliable reference genes for gene expression studies on Rhododendron 
molle G. Don. Front. Plant Sci 7, 1547, https://doi.org/10.3389/fpls.2016.01547 (2016).

411

32. Wang, C. et al. Identification and validation of reference genes for RT-qPCR analysis in non-heading Chinese cabbage flowers. Front. Plant Sci 7, 811, https://doi.org/10.3389/fpls. 2016.00811 (2016).

33. Fu, J., Wang, Y., Huang, H., Zhang, C. \& Dai, S. L. Reference gene selection for RT-qPCR analysis of Chrysanthemum lavandulifolium during its flowering stages. Mol Breeding 31, 205-215, https://doi.org/10.1007/s11032-012-9784-x (2013).

34. Gu, C. S. et al. Validation of reference genes for RT-qPCR normalization in Iris. lacteavar. chinensis leaves under different experimental conditions. Sci Hortic-Amsterdam 175, 144-149, https://doi.org/10.1016/j.scienta.2014.06.011 (2014).

35. Ma, L. L. et al. Selection and validation of reference genes for quantitative real-time PCR analysis in Iris bulleyana during flower color variation. Journal of Nuclear Agricultural Sciences 33, 1707-1716, (2019).

36. Saddhe, A., Malvankar, M. \& Kumar, K. Selection of reference genes for quantitative real-time PCR analysis in halophytic plant Rhizophora apiculate. PeerJ 6, e5226, https://doi.org/10.7717/ peerj.5226 (2018).

37. Ma, R., Xu, S., Zhao, Y., Xia, B. \& Wang, R. Selection and validation of appropriate reference genes for quantitative real-time PCR analysis of gene expression in Lycoris aurea. Front. Plant Sci 7, 536, https://doi.org/10.3389/fpls.2016.00536 (2016).

38. Fan, C. et al. Selection of reference genes for quantitative real-time PCR in bamboo (Phyllostachys edulis). PLoS One 8, e56573, https://doi.org/10.1371/ journal.pone.0056573 (2013).

39. Wang, H. B., Chen, S. M., Jiang, J. F., Zhang, F. \& Chen, F. D. Reference gene selection for 
cross-species and cross-ploidy level comparisons in Chrysanthemum spp. Sci Rep 5, 8094, https://doi.org/10.1038/srep08094 (2015).

40. Jia, Y. et al. Reference gene selection and validation by qRT-PCR during flower development and in different organs of Primula forbesii. J Hortic Sci Biotech 95, 383-394, https://doi.org/10.1080/ 14620316.2019 .1681909 (2019).

41. Tong, Z., Gao, Z., Wang, F., Zhou, J. \& Zhang, Z. Selection of reliable reference genes for gene expression studies in peach using real-time PCR. BMC Mol Biol 10, 71, https://doi.org/10.1186/ 1471-2199-10-71 (2009).

42. Wang, G. L. et al. Selection of reliable reference genes for quantitative RT-PCR in garlic under salt stress. PeerJ 7, e7319, https://doi.org/10.7717/peerj.7319 (2019).

43. Gu, C. S. et al. Reference gene selection for quantitative real-time RT-PCR normalization in Iris. lactea var. chinensis roots under cadmium, lead, and salt stress conditions. Sci World J 2014, 532713, https://doi.org/ 10.1155/2014/532713(2014).

44. Wang, M. \& Lu, S. Validation of suitable reference genes for quantitative gene expression analysis in Panax ginseng. Front. Plant Sci 6, 1259, https://doi.org/10.3389/fpls.2015.01259 (2016).

45. Gu, G. S. et al. De novo characterization of the Iris lactea var. chinensis transcriptome and an analysis of genes under cadmium or lead exposure. Ecotox Environ Safe 144, 507-513, https://doi.org/10.1016/ j.ecoenv.2017.06.071 (2017).

46. Taylor, S., Wakem, M., Dijkman, G., Alsarraj, M. \& Nguyen, M. A practical approach to RT-qPCR-Publishing data that conform to the MIQE guidelines. Methods 50, S1-S5, https://doi.org/10.1016/j.ymeth.2010.01.005 (2010).

47. Zhang, H. L. et al. Precocious flowering in trees: the FLOWERING LOCUS T gene as a research 
and breeding tool in Populus. J Exp Bot 61, 2549-2560, https:// doi:10.1093/jxb/erq092 (2010).

48. Livak, K. J. \& Schmittgen, T. D. Analysis of relative gene expression data using real-time quantitative PCR and the $2^{-\Delta \Delta \mathrm{Ct}}$ method. Methods 25, 402-408, https://doi.org/10.1006/ meth.2001.1262 (2001).

\section{Acknowledgements}

The work was supported by the National Natural Science Foundation of China (31801901), the Natural Science Foundation of Jiangsu (BK20180314, BK20180317), the Foundation of Key Laboratory of Landscaping (KF201901), Ministry of Agriculture and Rural Affairs, P.R.China, and the Jiangsu Key Laboratory for the Research and Utilization of Plant Resources (JSPKLB201814).

\section{Author contributions}

Y.W., H.Y. conceived and designed the experiments. Y.W., Y.Z., Q.L., Z.T. and L.L. performed the experiments and collected the data. Y.W., H.T. and S.H. prepared reagents/materials/analysis tools. Y.W. and C.G. analyzed the data; Y.W. wrote the paper. Y.W. and H.Y. revised the paper. All authors read and approved the manuscript.

\section{Additional information}

Supplementary Figure S1. Amplification results of 8 candidate genes with cDNA as templates. Lane1 EFla, 2 GAPDH, 3 ACT6, $4 U B Q, 5 U B C, 6 E F 1 \beta, 7$ PGK, 8 TUB. M: DL 2000 Plus DNA Marker (from up to low, 2000bp, 1000bp, 750bp, 500bp, 250bp, 100bp).

Supplementary Figure S2. Melting curves of 8 reference genes $(E F 1 \alpha, G A P D H, A C T 6, U B Q, U B C$, $E F 1 \beta, P G K$ and $T U B$ ) showing single peak.

Supplementary Table S1. Raw Cq values of the 8 candidate genes in different flowering stages and different genotypes of $I$. germanica cultivars. 


\section{Figure legends}

477 Figure 1. Cq values of the 8 candidate reference genes in all samples of I. germanica. Line across the 478 box-plot of $\mathrm{Cq}$ value depicts median values. The outside box is determined by the 25th and 75 th

479 percentiles. The whiskers represent the maximum and minimum values.

480 Figure 2. Average expression stability values (M) of 8 candidate reference genes predicted by GeNorm

481 software. The most stable genes are on the right, while the least stable genes are on the left.

482 Figure 3. Pairwise variation (V) of 8 candidate reference genes were calculated by GeNorm. Vn/Vn+1

483 value were used to determine the optimal number of reference genes.

484 Figure 4. Relative quantification of $I g F T$ gene expression in different cultivars of $I$. germanica using validated reference genes for normalization. (A) The expression level of $I g F T$ in '00246'. (B) The expression level of $I g F T$ in '2010200'. (C) The expression level of $I g F T$ in 'Elizabeth'. The bars represent standard errors. 
Figures

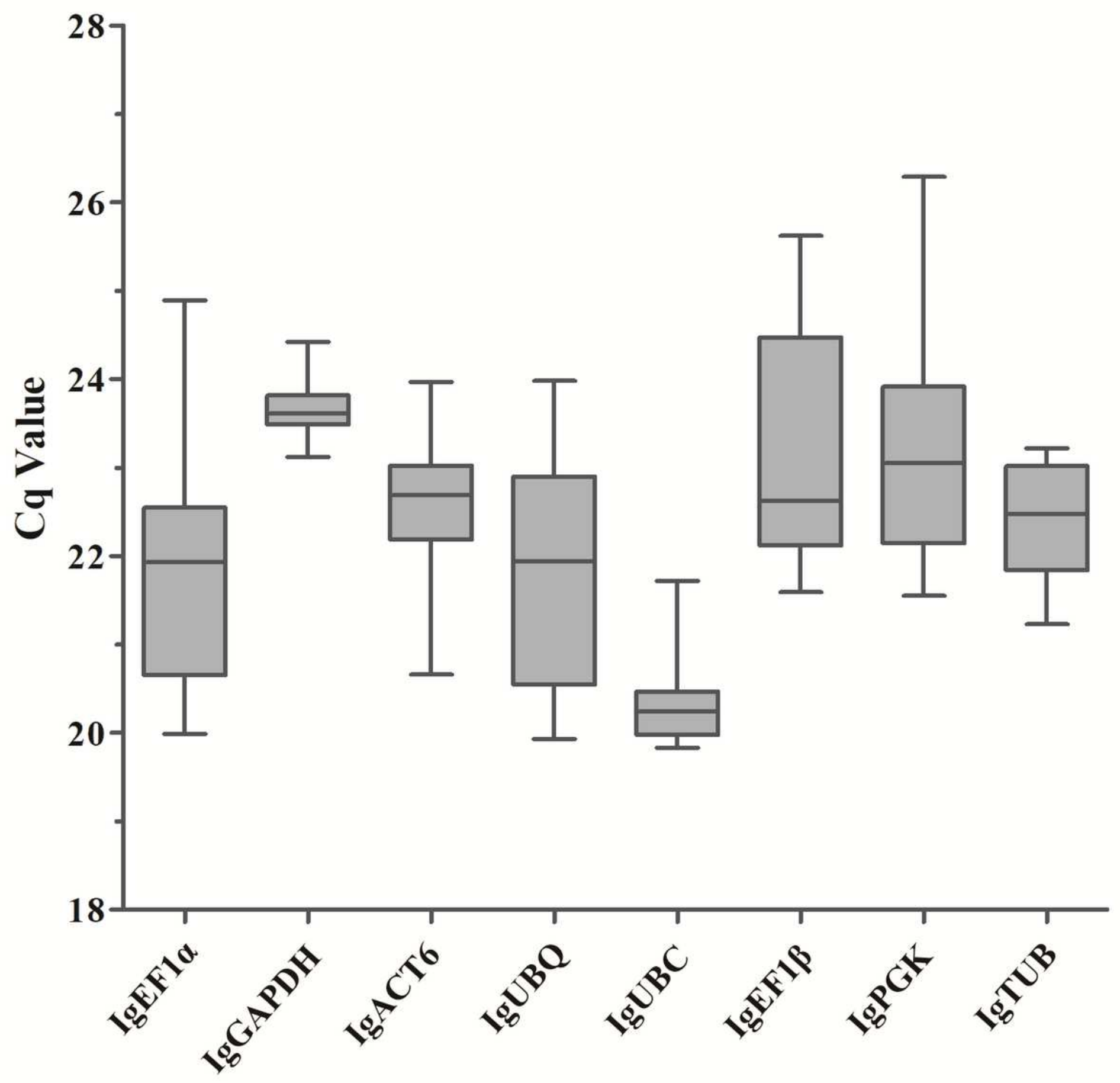

Figure 1

Cq values of the 8 candidate reference genes in all samples of I. germanica. Line across the box-plot of Cq value depicts median values. The outside box is determined by the 25th and 75th percentiles. The whiskers represent the maximum and minimum values. 
A

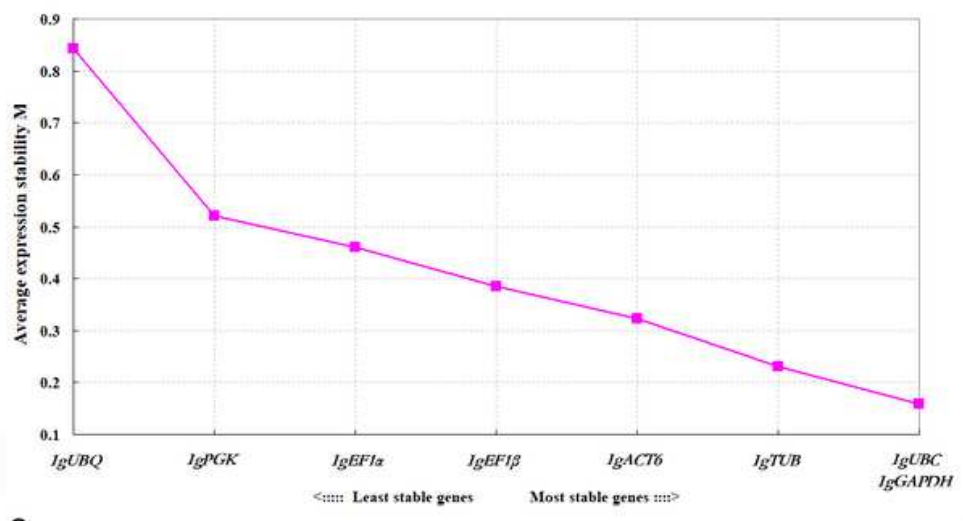

C

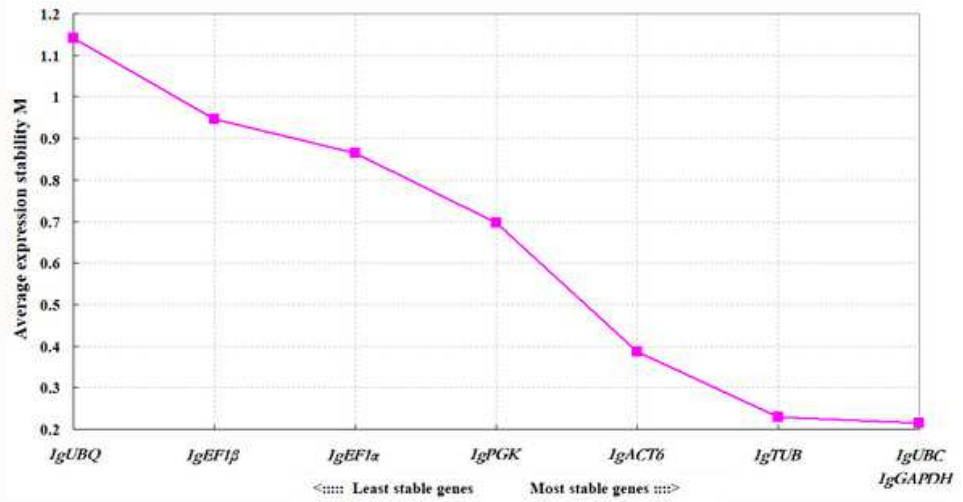

B

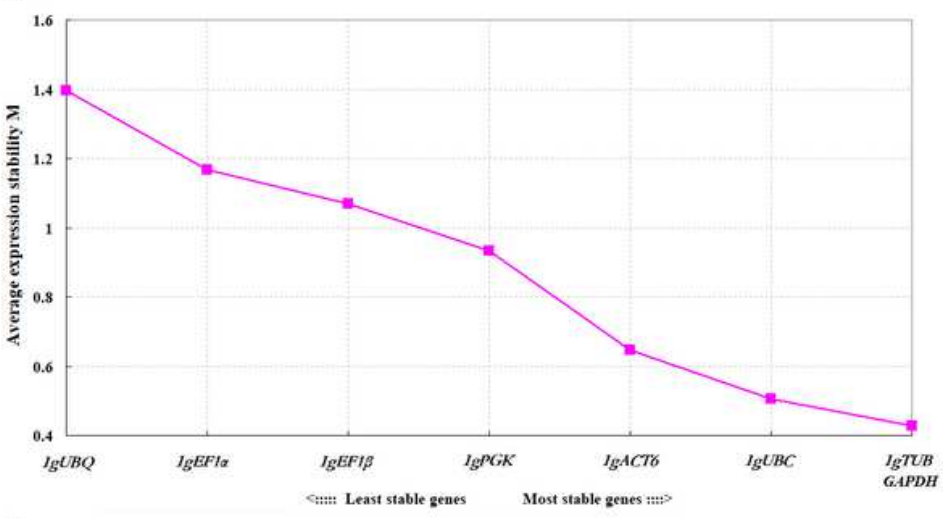

D

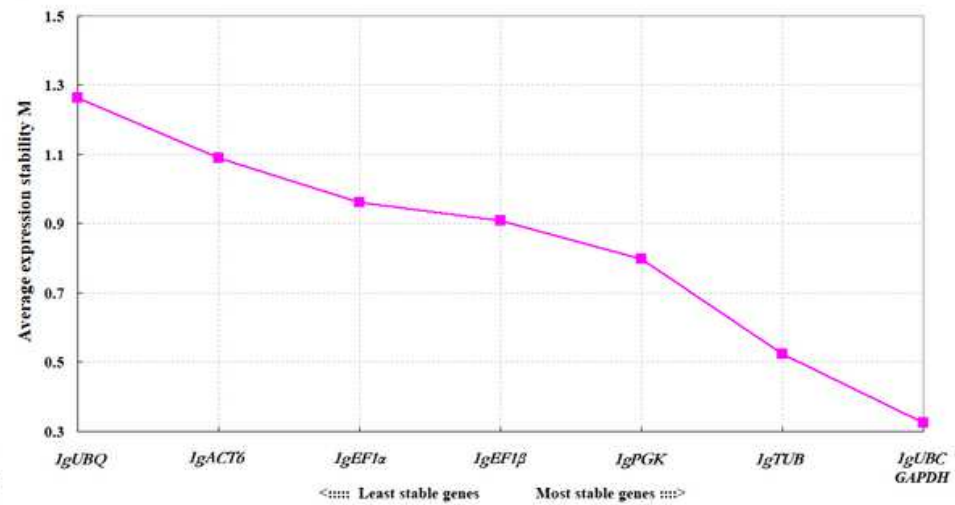

Figure 2

Average expression stability values $(\mathrm{M})$ of 8 candidate reference genes predicted by GeNorm software. The most stable genes are on the right, while the least stable genes are on the left. 

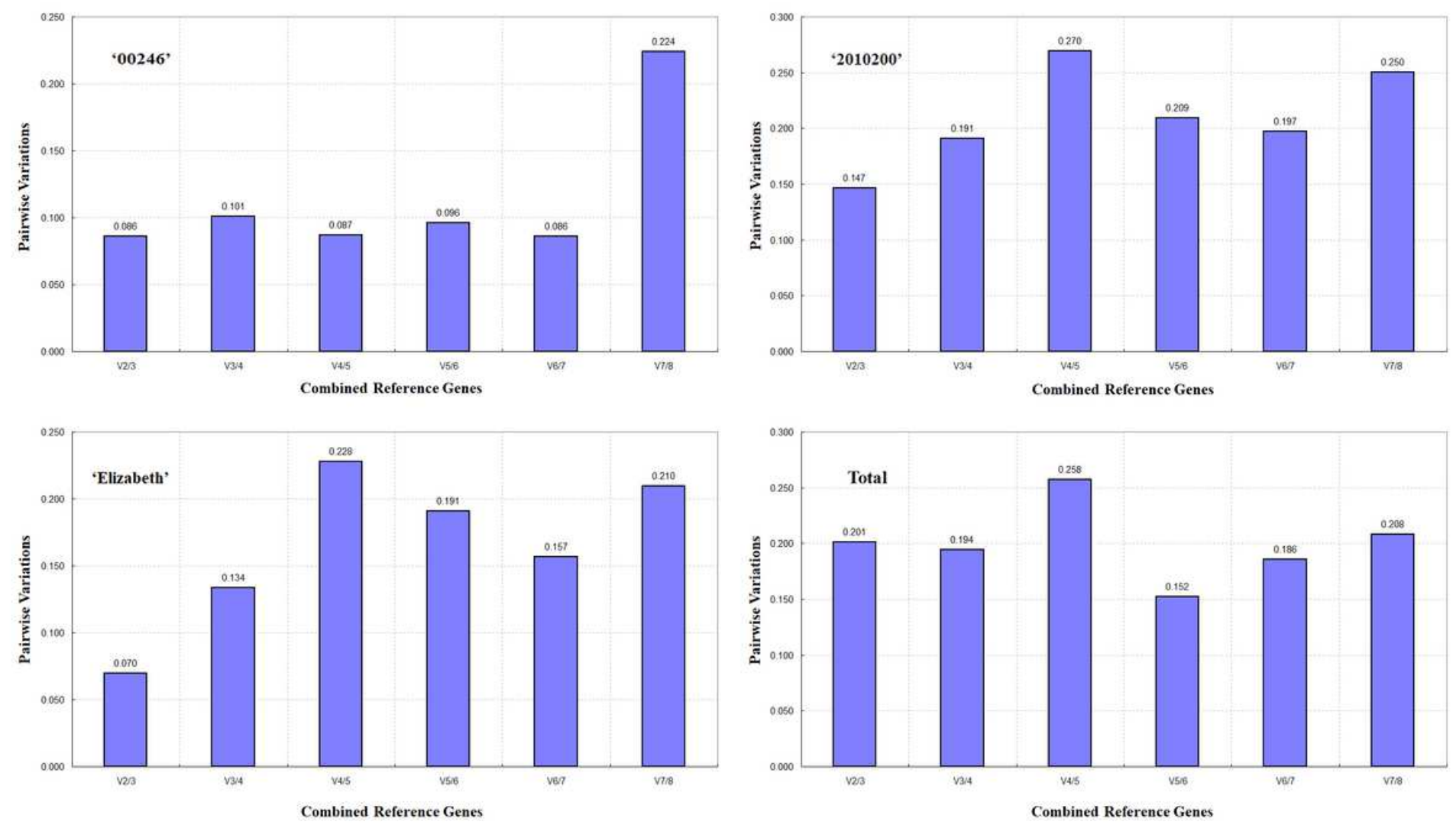

Figure 3

Pairwise variation (V) of 8 candidate reference genes were calculated by GeNorm. $V n / V n+1$ value were used to determine the optimal number of reference genes. 
A

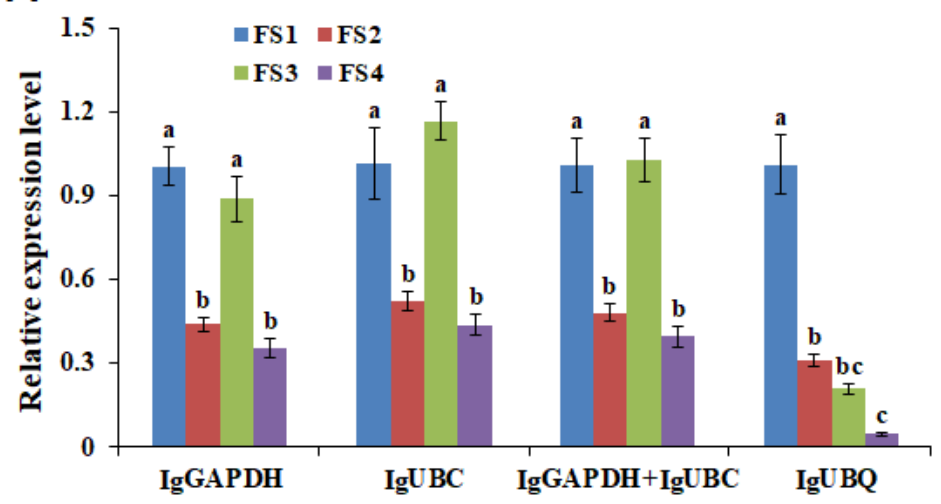

C

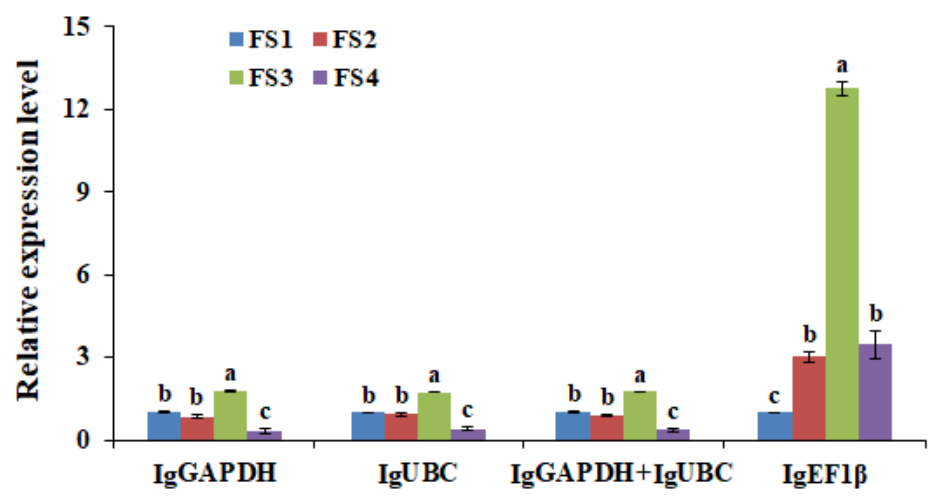

B

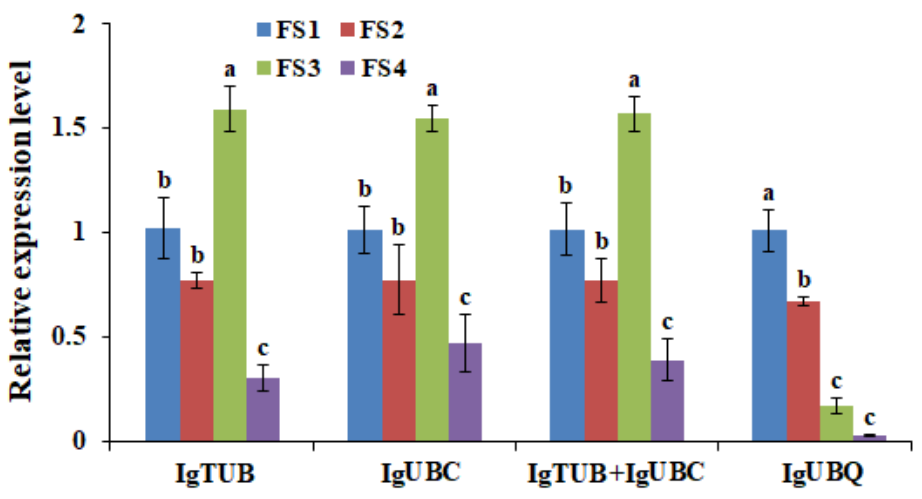

\section{Figure 4}

Relative quantification of IgFT gene expression in different cultivars of I. germanica using validated reference genes for normalization. (A) The expression level of IgFT in '00246'. (B) The expression level of IgFT in '2010200'. (C) The expression level of IgFT in 'Elizabeth'. The bars represent standard errors.

\section{Supplementary Files}

This is a list of supplementary files associated with this preprint. Click to download.

- Supplementaryfile.docx 